Japan. J. Med. Sci. Biol., 19, 239-245, 1966

\title{
ON A NEW TREATMENT REGIMEN WITH THIABENDAZOLE AGAINST ANCYLOSTOMA DUODENALE*
}

\author{
TATSUSHI ISHIZAKI, \\ Department of Parasitology, National Institute of Health, Tokyo \\ TOSHIHIKo IIJIMA AND YOICHI ITO \\ Department of Parasitology, Yamanashi Prefectural Hygiene Laboratory, Kofu
}

(Received: March 20th, 1966)

\begin{abstract}
The anthelmintic activity of thiabendazole syrup against Ancylostoma duodenale was investigated. Hookworm carriers (192) from the inhabitants of a village in Yamanashi Prefecture were treated under three dosage schedules. Before and after the administration, for the purpose of assessment, fecal examinations were performed by the thick smear method, the brine floatation method and quantitative direct smear method. Side effects were checked by direct questioning as well as the questionaire done for successive days. The negative conversion rates of eggs in feces were $52 \%$ with a single dose of $50 \mathrm{mg} / \mathrm{kg}, 63 \%$ with $25 \mathrm{mg} / \mathrm{kg}$ twice daily and $85 \%$ with $25 \mathrm{mg} / \mathrm{kg}$ twice daily for two days. The negative conversion rates were $72 \%, 77 \%$ and $96 \%$, in the order mentioned above, in the group of the light infestation, $44 \%, 74 \%$ and $82 \%$ in the moderate infestation group, and $17 \%, 100 \%(3 / 3)$ and $68 \%$ in the heavy infestation group. Main side effects were dizziness and fatigue which appeared in $33 \%$ and $13 \%$ of the patients, respectively, with a single dose of $50 \mathrm{mg} / \mathrm{kg}$. These side effects reduced markedly with $25 \mathrm{mg} / \mathrm{kg}$ twice daily. However, it increased with $25 \mathrm{mg} / \mathrm{kg}$ twice daily for two days.
\end{abstract}

\section{INTRODUCTION}

There are many reports concerning the noticeable anthelmintic efficacy of Thiabendazole on human helminths (Franz, 1963; Huang and Browm, 1963; Papasarathorn, Chulareak and Tong-Koom, 1964; Salunkhe, Gaitonde and Vakil, 1964; Betero, 1965; Franz, Schneider and Pohlman, 1965; Most, et al., 1965; Shah, 1965). There are also similar reports in Japan (Yanagisawa et al., 1963; Iwata et al., 1963; Noda, 1964 ; Yamazaki, 1964). The authors have already reported on the anthelmintic effect of thiabendazole syrup on human helminths (Ishizaki, Iijima and Ito, 1963). Further study was performed on Ancylostoma duodenale with special emphasis on an efficient treatment with minor side effects.

\section{MATERIALS AND METHODS}

One hundred and ninety-two hookworm carriers were chosen from inhabitants of a village in Yamanashi Prefecture. Ages of the carriers ranged from 6 to 80 years, the

* This investigation was presented to the First International Congress of Parasitology in Rome, 1964.

石崎 達 (国立予防衛生研究所寄生虫部)

飯島 利彦・伊藤 洋一 (山梨県立衛生研究所地方病科) 
majority of whom were 20 to 60 years old; and male and female were almost equal in number. According to the larva culture method (Harada and Mori, 1951.), the sole prevalence of Ancylostoma duodenale was observed in this area.

Thiabendazole syrup with the concentration of $0.2 \mathrm{~g} / \mathrm{ml}$ was given at least two hours after meal. During the treatment, carriers were prohibited from taking alcoholic beverages and greasy foods, and instructed to take rest. Carriers were divided into the following three groups according to the dosage schedules.

Group I (67 carriers): $50 \mathrm{mg} / \mathrm{kg}$ with a single dose in the morning.

Group II (52 carriers): $25 \mathrm{mg} / \mathrm{kg}$ twice daily in the morning and evening $(50 \mathrm{mg} / \mathrm{kg}$ in total).

Group III (73 carriers) : $25 \mathrm{mg} / \mathrm{kg}$ twice daily for two days in the morning and evening $(100 \mathrm{mg} / \mathrm{kg}$ in total)

Anthelmintic effects of a drug in a mass-treatment differs markedly according to the degree of infestation of the worm. The objects were divided into three groups in order that each group included objects with every different infestation at the same ratios, as shown in Table 1. For detection of eggs of the carriers, fecal examinations by the thick smear method with cellophane (Kato, 1958 ; Komiya et al., 1960), the brine floatation method, and a quantitative direct smear method (Ishizaki, 1953) instead of Stoll's eggcounting technique, were used before and 22nd days after administration. The negative conversion rates of eggs and the egg-reduction rates in feces were used for the assessment of anthelmintic effects in each group. The negative conversion rate of feces represents the rate of persons who showed the absence of eggs in their feces after the treatment in subjected group. Side effects were checked by direct questioning to the individuals at the first administration of the drug and by the questionaire on the symptomes which appeared on the following day.

\section{RESULTS}

\section{Evaluation of Anthelmintic Effects in the Three Dosage Groups}

The results obtained are shown in Table 2. Both rates of the negative conversion and the egg-reduction were obtained on the 22nd day after administration. According to the negative conversion rates, anthelmintic effects in the three groups were $52 \%, 63 \%$ and $85 \%$ in Groups I, II and III, respectively. The difference of the rates between Group III and the other two was statistically significant $(\mathrm{P}<0.05)$. The egg-reduction rates were $68 \%, 76 \%$ and $98 \%$ in Groups I, II and III, respectively. The difference of the rates between Group III and the other two was also significant $(\mathrm{P}<0.05)$.

The anthelmintic effects of thiabendazole was not decreased by the administration with $25 \mathrm{mg} / \mathrm{kg}$ twice daily (Group II) as compared with a single dose of $50 \mathrm{mg} / \mathrm{kg}$ (Group I). The effects with $25 \mathrm{mg} / \mathrm{kg}$ twice daily for two days (Group III) was the highest among the three dosage schedules.

\section{Evaluation of Anthelmintic Effects in the Three EPG Groups}

Since the anthelmintic effects must be compared in the group of the same intensity of infestation, each of three groups was further divided into three sub-groups according to the EPG of the individuals. Sub-groups A, B and C consist of individuals with EPG of less than 200, from 201 to 1,000 and more than 1,001, respectively. The results are shown in Table 3. 
Table 1. Results of pre-treatment examination of hookworn infections in three groups

\begin{tabular}{|c|c|c|c|c|c|c|}
\hline \multirow{2}{*}{ EPG count } & \multicolumn{2}{|c|}{ Group I } & \multicolumn{2}{|c|}{ Group II } & \multicolumn{2}{|c|}{ Group III } \\
\hline & $\begin{array}{l}\text { No. of } \\
\text { cases }\end{array}$ & $\%$ & $\begin{array}{l}\text { No. of } \\
\text { cases }\end{array}$ & $\%$ & $\begin{array}{l}\text { No. of } \\
\text { cases }\end{array}$ & $\%$ \\
\hline-100 & 24 & 35.8 & 18 & 34.7 & 18 & 24.6 \\
\hline-200 & 8 & 11.6 & 12 & 23.1 & 9 & 12.3 \\
\hline-300 & 4 & 6.0 & 11 & 21.1 & 4 & 5.5 \\
\hline-400 & 3 & 4.5 & 2 & 3.9 & 9 & 12.3 \\
\hline-500 & 2 & 2.9 & 3 & 5.8 & 8 & 11.0 \\
\hline-600 & 4 & 6.0 & 1 & 1.9 & 3 & 4.1 \\
\hline-700 & 4 & 6.0 & 1 & 1.9 & 0 & 0 \\
\hline-800 & 1 & 1.5 & 1 & 1.9 & 2 & 2.7 \\
\hline-900 & 4 & 6.0 & 0 & 0 & 0 & 0 \\
\hline$-1,000$ & 1 & 1.5 & 0 & 0 & 1 & 1.4 \\
\hline$-1,200$ & 3 & 4.5 & 0 & 0 & 2 & 2.7 \\
\hline$-1,400$ & 3 & 4.5 & 1 & 1.9 & 3 & 4.1 \\
\hline$-1,600$ & 0 & 0 & 0 & 0 & 1 & 1.4 \\
\hline$-1,800$ & 1 & 1.5 & 0 & 0 & 1 & 1.4 \\
\hline$-2,000$ & 0 & 0 & 0 & 0 & 2 & 2.7 \\
\hline$-2,500$ & 1 & 1.5 & 0 & 0 & 2 & 2.7 \\
\hline$-3,000$ & 3 & 4.5 & 0 & 0 & 0 & 0 \\
\hline$-4,000$ & 0 & 0 & 0 & 0 & 1 & 1.4 \\
\hline$-5,000$ & 0 & 0 & 1 & 1.9 & 3 & 4.1 \\
\hline $5,000-$ & 1 & 15. & 1 & 1.9 & 4 & 5.5 \\
\hline Total & 67 & 100 & 52 & 100 & 73 & 100 \\
\hline
\end{tabular}

Table 2. The negative conversion rate of eggs and the egg-reduction rate in feces in three dosage schedules

\begin{tabular}{|c|c|c|c|c|c|c|c|c|}
\hline \multirow{2}{*}{ Group } & \multirow{2}{*}{ Dosage } & \multirow{2}{*}{$\begin{array}{l}\text { Total number } \\
\text { of examined }\end{array}$} & \multicolumn{3}{|c|}{ Negative conversion } & \multicolumn{3}{|c|}{ Egg-reduction } \\
\hline & & & $\begin{array}{c}\text { No. of } \\
\text { examined }\end{array}$ & $\begin{array}{l}\text { No. of } \\
\text { negative }\end{array}$ & $\%$ & $\begin{array}{l}\text { No. of } \\
\text { examined }\end{array}$ & $\begin{array}{l}\text { No. of } \\
\text { reduction }\end{array}$ & $\%$ \\
\hline I & $\begin{array}{l}50 \mathrm{mg} / \mathrm{kg} \\
\text { (Single) }\end{array}$ & 67 & 67 & 35 & 52.2 & 60 & 41 & 68.3 \\
\hline II & $\begin{array}{c}50 \mathrm{mg} / \mathrm{kg} \\
(25 \mathrm{mg} / \mathrm{kg} \times 2)\end{array}$ & 52 & 49 & 31 & 63.2 & 49 & 37 & 75.5 \\
\hline III & $\begin{array}{c}100 \mathrm{mg} / \mathrm{kg} \\
(25 \mathrm{mg} / \mathrm{kg} \times 4)\end{array}$ & 73 & 62 & 53 & 85.0 & 62 & 61 & 98.0 \\
\hline
\end{tabular}

The negative conversion rates of eggs in Sub-group A were $72 \%, 77 \%$ and $96 \%$ in Groups I, II and III, respectively. In Sub-group B, the rates were $44 \%, 74 \%$ and $82 \%$ in Groups I, II and III, respectively, and in Sub-group C the rates were $16 \%$, $100 \%(3 / 3)$ and $68 \%$, respectively.

In these results, thiabendazole was most effective in the case of light infestation of 
Table 3. The negative conversion rate under various grades of EPG

\begin{tabular}{|c|c|c|c|c|c|c|c|c|c|c|}
\hline \multirow{2}{*}{$\begin{array}{l}\text { Sub- } \\
\text { group }\end{array}$} & \multirow{2}{*}{ EPG } & \multicolumn{3}{|c|}{$\begin{array}{c}\text { Group I } \\
(50 \mathrm{mg} / \mathrm{kg} \times 1)\end{array}$} & \multicolumn{3}{|c|}{$\begin{array}{c}\text { Group II } \\
(25 \mathrm{mg} / \mathrm{kg} \times 2)\end{array}$} & \multicolumn{3}{|c|}{$\begin{array}{c}\text { Group III } \\
(25 \mathrm{mg} / \mathrm{kg} \times 4)\end{array}$} \\
\hline & & $\begin{array}{c}\text { No. of } \\
\text { examined }\end{array}$ & $\begin{array}{l}\text { No. of } \\
\text { negative }\end{array}$ & $\%$ & $\begin{array}{l}\text { No. of } \\
\text { examined }\end{array}$ & $\begin{array}{l}\text { No. of } \\
\text { negative }\end{array}$ & $\%$ & $\begin{array}{l}\text { No. of } \\
\text { examined }\end{array}$ & $\begin{array}{l}\text { No. of } \\
\text { negative }\end{array}$ & $\%$ \\
\hline A & $\begin{array}{l}\text { less than } \\
200\end{array}$ & 32 & 23 & 71.8 & 30 & 23 & 77.0 & 27 & 26 & 96.0 \\
\hline B & $201-1,000$ & 23 & 10 & 43.5 & 19 & 14 & 73.7 & 27 & 22 & 82.0 \\
\hline $\mathrm{C}$ & $\begin{array}{l}\text { more than } \\
1,001\end{array}$ & 12 & 2 & 16.6 & 3 & 3 & - & 19 & 13 & 68.0 \\
\hline
\end{tabular}

the worm (Sub-group A). A single dose of $50 \mathrm{mg} / \mathrm{kg}$ was sufficient for the mass-treatment with a single or divided use, and a dose of $25 \mathrm{mg} / \mathrm{kg}$ twice daily for two days was considered to expect a complete cure. In the case of moderate infestation (Sub-group B), this drug was not effective with a single dose of $50 \mathrm{mg} / \mathrm{kg}$, but effective with both 25 $\mathrm{mg} / \mathrm{kg}$ twice daily and $25 \mathrm{mg} / \mathrm{kg}$ twice daily for two days. In the case of heavy infestation (Sub-group C), the negative conversion rate was $68 \%$ only with $25 \mathrm{mg} / \mathrm{kg}$ twice daily for two days and no effects were observed in others.

\section{Side Effects}

Side effects obtained from Groups I and II are presented in Table 4. Side effects appeared within a half or one hour after the first administration and disappeared mostly within the next one hour. Side effects lasted for more than three hours in some cases, but there was no one who complained of any disturbance on the following day. Side effects were observed in $41 \%$ of the carriers in Group I, and $33 \%$ of the carriers complained of dizziness, $13 \%$ of fatigue, $7 \%$ of nausea, $6 \%$ of weakness, $3 \%$ of vomiting, and $3 \%$ of headache. Thirteen per cent of the carriers complained of side effects in Group II, and $9 \%$ of dizziness, $4 \%$ of headache and $2 \%$ of nausea.

As shown in Table 5, side effects appeared markedly after the 4th administration in Group III. After the first administration, $9 \%$ of the carriers complained of side effects

Table 4. Side effects observed in Group I and Group II

\begin{tabular}{|c|c|c|c|c|}
\hline \multirow{2}{*}{ Side effect } & \multicolumn{2}{|c|}{$\begin{array}{c}\text { Group I } \\
(50 \mathrm{mg} / \mathrm{kg} \times 1)\end{array}$} & \multicolumn{2}{|c|}{$\underset{(25 \mathrm{mg} / \mathrm{kg} \times 2)}{\text { Group II }}$} \\
\hline & No. of cases & $\%$ & No. of cases & $\%$ \\
\hline Examined & 70 & 100 & 55 & 100 \\
\hline Complained & 29 & 41.4 & 7 & 12.7 \\
\hline Dizziness & 23 & 32.8 & 5 (slight) & 9.3 \\
\hline Nausea & 5 & 7.1 & 1 & 1.8 \\
\hline Vomiting & 2 & 2.8 & 0 & 0 \\
\hline Fatigue & 9 & 12.8 & 0 & 0 \\
\hline Headache & 2 & 2.8 & 2 & 3.5 \\
\hline Weakness & 4 & 5.8 & 0 & 0 \\
\hline
\end{tabular}


and $49 \%$ complained at the end of the 4 th administration, i. e. $24 \%$ of the carriers complained of dizziness, $21 \%$ of headache, $15 \%$ of anorexia, $13 \%$ of fatique, $12 \%$ of nausea, $7 \%$ of weakness, $4 \%$ of stomachache, $4 \%$ of diarrhea, $4 \%$ of constipation, and $3 \%$ of urticaria. These side effects, however, disappeared on the following day.

Table 5. Side effects observed in Group III

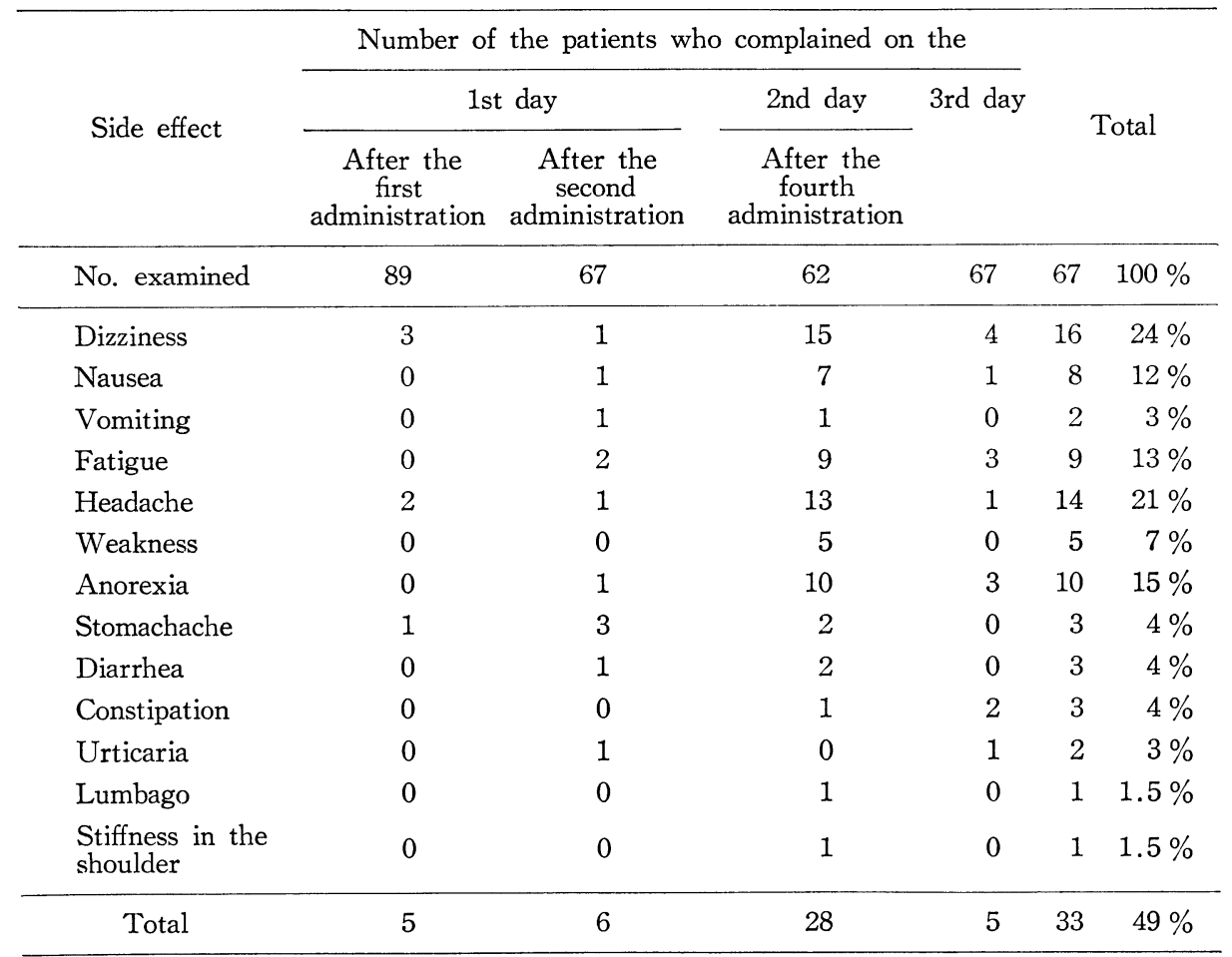

\section{DISCUSSION}

The results obtained from Group II showed that the anthelmintic effects of thiabendazole seemed to be additive or cumulative against hookworms. These effects were seen also in Group III, in which the negative conversion rate of $85 \%$ was obtained by a repeated usage of a small dose of $25 \mathrm{mg} / \mathrm{kg}$. It was well known that tetrachlorethylene (Komiya, Nakayama and Tsukagoshi, 1959) and 1-bromo-2-naphthol (Komiya et al., 1964), each of which is commonly used at present for the removal of hookworms, showed a marked decrease of its efficacy when used in divided doses for the purpose of reduction of side effects. The anthelmintic effects of thiabendazole, however, was not reduced by the divided administrations (Group II), and the effects increased with further repeated administration of the small dose (Group III). These particular effects of thiabendazole were substantiated by the present paper.

Since this drug was found to be anthelmintic in the laboratory and domestic animals, side effects was observed carefully in this work. Side effects reduced markedly in a dose of $25 \mathrm{mg} / \mathrm{kg}$ twice daily as compared with those in a single dose of $50 \mathrm{mg} / \mathrm{kg}$, but 
increased markedly in that of $25 \mathrm{mg} / \mathrm{ks}$ twice daily for two days. In general, a pharmacological action is closely related to the amount of a drug given at one time and it decrease with the lapse of time. The side effects mentioned above suggest that the action of thiabendazole on the human body continues to the 2nd administration performed 12 hours after the first one. Many side effects manifest up to the 4th administration.

From the results of this study, an adequate treatment regimen of thiabendazole, the most effective to the worms and the most harmless to the human body, is to be a multiple usage of a small dose with a sufficient interval to avoid major side effects. One example is an administration of $25 \mathrm{mg} / \mathrm{kg}$ twice daily with an interval of 12 hours.

\section{REFERENCES}

BEtERO, R. D. (1965) : Treatment of human intestinal helminthiases with thiabendazole. Am. J. Trop. Med. Hyg., 14, 618-621.

FRANZ, K. H. (1963) : Clinical trials with thiabendazole against human Strongyloidiasis. Am. J. Trop. Med. Hyg., 12, 211-214.

Franz, K. H., Schneider, W. J. And Pohlman, M. H. (1965) : Clinical trials with thiabendazole against intestinal nematodes infecting humans. Am. J. Trop. Med. Hyg., 14, 383-386.

HARADA, Y. AND MORI, O. (1951): A simple method for the cultivation of hookworm larvae. Medicine and Biology, 20, 65-67 (text in Japanese).

HuANG, W. H. AND BROWn, H. W. (1963): The efficacy of thiabendazole against hookworm and ascaris of man. J. Parasitol., 49, 1044-1018.

IsHIZAKI, T. (1953) : Clinical studies on ascariasis. I. A new egg couning method in direct smear specimens. Japan. J. Parasitol., 2, 137-142 (text in Japanese).

IsHIZAKI, T., IIJIMA, T. AND ITO, Y. (1963): Studies on anthelmintic effects of thiabendazole I. Japan. J. Parasitol., 12, 182-185 ((text in Japanese with English summary).

Iwata, S., Araki, T., Ueda, G., WadA, T. AND KIDA, A. (1963) : Treatment of intestinal parasitosis with MK-360. Bull. Osaka. Med. Sch., 9, 23-30.

KATO, K. (1958): Comparative study on the new direct smear method with celophane and floating method in mass-examination of feces. Japan. J. Parasitol.,7, 239 (text in Japanese).

KomiYa, Y. NAKAYAma, K. AND TsukaGOSHI, K. (1959) : Mass treatment against hookworm without any purgative. III. A divided usage of tetrachlorethylene. Rinsho-Shyokakibyogaku (Clinical Gastroenterology), 7, 89-92 (text in Japanese).

Komiya, Y., Kobayashi, A., Kumada, M., Kutsumi, H. And Kojima, K. (1960) : Study on thick smear technic with cellophane cover for stool examination for helminth ova. Japan. J. Parasitol., 9, 61-68 (text in Japanese with English summary).

Komiya, Y., Kobayashi, A., Kumada, M. And Kutsumi, H. (1964) : Trial of establishing the standard therapeutic regime with 1-bromo-2-naphtol (Wormin) in the mass treatment of hookworm infection and comparison of anthelmintic efficacies of two different forms of the compound, granule and capsule. Japan. J. Parasitol., 12, 415-425 (text in Japanese with English summary).

Mosy, H., Yoeli, M., Campbell, W. C. ANd Cuckler, A. C. (1965) : The treatment or Strongyloides and Enterobius infections with thiabendazole. Am. J. Trop. Med. Hyg., 14, 379-382.

NoDA, R. (1964) : Studies on Strongyloides of horse-kinds of parasites I. Japan. J. Parasitol., 13, 344 (text in Japanese).

Papasarathorn, T., Chularerk, U. and Tongkoom, B. (1964): Studies on the therapeutic effects of thiabendazole against Ascaris, Strongyloides and hookworm infection. Japan. I. Med. Sci. Biol., 17, 217-221.

Salunkhe, D. S., Gattonde, B. B. ANd Vakil, B. J. (1964): Clinical evaluation of a new 
anthelmintic-thiabendazole [2-(4'-thiazolyl)-benzimidazole]. Am. J. Trop. Med. Hyg., 13, $412-416$.

SHAH, K. S. (1965) : Observation on clinical trials with thiabendazole on over 400 patients with mixed intestinalhelminthiasis. The Medicus, 29, 189-203.

YAMAZAKI, N. (1964): Experiment of the effect of thiabendazole on the growth process of hookworm. Japan. J. Parasitol., 13, 364 (text in Japanese).

Yanagisawa, R., Uchida, A., NozUe, S., Kondo, T. AND KARUBE, F. (1963): Anthelmintic effect of thiabendazole (MK-360) on the nematodes parasitic in human intestine. J. Chiba Med. Soc., 38, 523-530. 